\title{
CUSTOMS PROCEDURES IN UKRAINIAN LEGISLATION: THE ISSUES OF CONCEPT, SYSTEM AND EUROPEANIZATION
}

\section{Kormych B. A.}

\section{INTRODUCTION}

The history of diversity of rules for a customs clearance of goods, which led to the application of different treatment to goods due to declared purpose of its movement across customs frontiers, can be traced back to the beginning of 19th century. That happened because of the transformation of the views on customs duties, which started to be viewed not as a charge for transportation of goods, as it used to be common in Europe for many centuries before, but as a consumption tax ${ }^{1}$. Eventually the movement of goods across customs frontiers for purposes, other than consumption or trade, becomes the basis for application of exemptions from customs duties and other indirect taxes. That, in turn, led to the creation of separate customs clearance procedures for such cases, which had to guarantee the implementation of the conditions for granting exemptions from taxation. A terminology, which is applied to such set of rules, differs from state to state. The most commons terms are «customs regimes» and «customs procedures».

For example, a procedure of customs warehousing was introduced in England in 1803 for such goods as tea, tobacco, coffee, wine and spirits $^{2}$. In the French customs legislation this type of procedure was established in $1832^{3}$. The modern concept of transit started to form in the same period, which initially was concerned with transit duties, that comprised a proportion of conventional import duties ${ }^{4}$. The abolition of

\footnotetext{
${ }^{1}$ Кормич Б.А. Історія розвитку митної справи в Свропі: періодизація та основні тенденції. Lex Portus. 2016. № 1. С. 59.

${ }^{2}$ Encyclopedia Britannica Dict. A.S.L.G.I. 11th Ed. Chisholm. 1910-1911-1922. 33 vols. Vol. 4. p. 200. URL: https://archive.org/stream/EncyclopaediaBritannicaDict.a.s.l.g.i. 11thed.chisholm.1910-1911-1922.33vols/04.EncycBrit.11th.1910.v.4.BIS-

CAL.\#page/n217/mode/2up

${ }^{3}$ Asakura H. World History of the Customs and Tariffs. World Customs Organization, 2003. P. 214.

${ }^{4}$ Nicali A. Customs History. A Historical Outlook on the Italian Customs Policy. P. 15.
} 
transit duties in certain European countries began only in the middle of the nineteenth century. At the same time, another countries, such as the then Russian Empire, did not recognize transit at all applying ordinary import duties to goods in transit. The final recognition of the freedom of transit occurred only after the Barcelona Convention on the Freedom of Transit of 1921 was signed. The Art. 3 that Convention prohibited the taxation of transit traffic by any kind of transit, import or export duties ${ }^{5}$. The rules for temporary admission, merely for commercial samples for that time, were introduced in the International Convention relating to the simplification of customs formalities, signed in Geneva on November 2, 1923 (Art. 10, 16 and the annex to Art. 16) ${ }^{6}$.

Considering above mentioned, we can highlight two basic functions of the modern system of customs procedures:

a) formation of the system of exemptions from taxation and application of non-tariff measures on conditions of specific use of goods;

b) regulation of customs authorities' workflow, as well as actions of respective non-state subjects, for performing customs and (in some cases) other border formalities.

The latter is very important for overall state of border management in a particular country so far the customs procedures determine treatment which is applied to the goods in question and also to the all non-state actors involved into foreign trade transactions. So, it can be argued, that the approach to the role and place of customs procedures within the customs legislation may reflect the general public administration model which is adopted for border management. According to this, the views on public sector transformation from the «Old Public Management» to the «New Public Service» ${ }^{7}$ may be utilized for understanding the differences between the concepts of «customs regimes» and «customs procedures». Besides, $i$ the modern State is bind with a wide range of international (World Customs Organisation) and regional (regional free trade associations) standards in the issues of application of customs

5 Convention and Statute on Freedom of Transit. Barcelona, 20 April of 1921. League of Nations Treaty Series. Vol. 7. Pp. 12-33.

${ }^{6}$ International Convention Relating to the Simplification of Customs Formalities, and Protocol of Signature. Geneva, 3 November 1923. Australian Treaty Series. 1925. No. 14.

7 Robinson M. From Old Public Administration to the New Public Service. Implications for Public Sector Reform in Developing Countries. Singapore: UNDP Global Centre for Public Service Excellence. 2015. P. 4. 
procedures, which erects an issue of influence of such standards on national administrative procedures, which is subject to transnational and global administrative law theories. Furthermore, in the case of European countries this is supplemented with the issue of europeanization of the respective legislation.

\section{Customs Regimes vs. Customs Procedures: Why the Term Really Matters}

The development of the initial concept of customs regimes in Ukrainian law started in in the mid-1990's. In particular, one of the first ways to address this topic, was the characterizing customs regimes as a one of means of a customs policy implementation ${ }^{8}$.

However, Ukrainian customs legislation of that time did not define customs regimes, but operated the term «purpose of moving goods across customs frontiers», setting only three of them: a free use; a temporary importation or exportation; a transit. That classification covered various types of foreign trade transactions. So that, any classifications of customs regimes of that time were based not on legislative definitions, but on the analysis of the rules for specific procedures for particular goods. Moreover, at that time, customs regimes were established not only by the Customs Code of Ukraine of 1992, but also by a number of supplementary legislative acts ${ }^{9}$.

Legal definition of «customs regime», as well as the exhaustive list of that regimes had been provided only in the second Customs Code of Ukraine of 2002 (which was later repelled). In addition, Customs Code 2002 included the provision that customs regimes was to be set solely by the Code. Basing on that regulations, Ukrainian law adopted the concept of customs regimes, which used a certain analogy with administrative legal regimes. In accordance to that approach «...customs regimes, as well as other types of administrative-legal regimes, should be considered as a sub-institute of administrative law» ${ }^{10}$.

8 Кивалов С.В. Средства осуществления таможенной политики Украины. Одесса: Астропринт, 1995. С. 20-27.

9 Кормич Б.А. Державно-правовий механізм митної політики України : монографія. Одеса: Астропринт, 2000. С. 135-137.

10 Крестьянинов О.О. Правове регулювання митних режимів : автореф. дис... канд. юр. наук: 12.00.07. Х.: Національна юридична академія України ім. Ярослава Мудрого, 2008. С. 11. 
Idea of administrative origin of customs regimes shifts the emphasis on finding common features between administrative and customs regimes, such as its content, structure and order of application.

However, the concept of the common background of administrative and customs regimes suffers a significant drawback: the views of Ukrainian (in fact - the post-soviet) jurisprudence upon the nature of legal regimes in administrative law. Due to that views the main purpose of administrative legal regimes lays within the State's function to protect public security and to response to possible or emerging security threats, thus «the grindstone of the administrative legal regimes' social function is the presence of elements of administrative coercion, restrictions and prohibitions that limit human rights ${ }^{11}$. In fact, the administrative legal regimes are a certain exception to the general order public authorities functioning and consist of special «regime» rules of conduct.

At the same time, the system of customs regimes creates an ordinary procedure for the movement of goods across customs frontiers, since, in fact, it is not provided any other procedure then placing goods under a particular customs regime. In addition, the current Customs Code of Ukraine of 2012 (CCU) gives a clear answer to the question of the customs regimes' function, which according to Part 1 of Art. 70 $\mathrm{CCU}$ is «the application of the Ukrainian legislation on state customs affairs» ${ }^{12}$.

Furthermore, from these position one can notice certain inconsistency in the definition of customs regimes, which is provided in Para. 25 of Art. $4 \mathrm{CCU}$, as a «complex of interrelated legal norms that according to the stated purpose of moving goods across the Ukrainian customs frontier determine the customs procedure for these goods, its legal status, taxation rules and determine its use after customs clearance». But in fact, «the purpose of the movement of goods across the customs frontier» and «the use of goods after customs clearance» are definitely the same thing. Basically, physical and legal persons import or export goods for the purpose of its use in a particular way. And the desired way of use of goods is the exact factor that determines the application of the procedure, tariff non-tariff regulation, etc.

11 Настюк В.Я. Белєвцева В.В. Адміністративно-правові режими в Україні : монографія Харків: Право, 2009. С. 29.

12 Митний кодекс України від 13.03.2012. № 4495-VI. Офіціийний вісник України. 2012. № 32. С. 1175. 
In the above mentioned definition we rather see an attempt to impose extra regulative restrictions and to speculate that it is not the holder of procedure, but a customs authority is the subject who defines the way the goods in question shall be used after a customs clearance. This assessment concerns not merely rules on customs regimes, but generally passes as a red line through the whole $\mathrm{CCU}$, which provisions are written from the point of view of customs authorities, not from the side of non-state actors involved in foreign trade. From this point the approach discussed is pretty common for classic public administration theory where «The public service was governed by precisely prescribed rules and... thus, it was expected to exercise minimal discretion in executing its tasks» ${ }^{13}$. Furthermore, in Ukrainian case the emphasis on control and compliance is multiplied by «local heritage» of the lack of respect to good governance principles, such as rule of law and due process.

Apparently the peculiarities of the above discussed approach are caused by the fact, that the whole concept of customs regimes has not been common for soviet legislation, where the roots of Ukrainian administrative law are. That concept has been brought from international rules and standards for customs procedures, basically from the instruments of the World Customs Organization (WCO). But returning to the historical background of specific rules for customs procedures, we once again face the «clear situation when a specific set of national rules and principles of administrative procedures, that is common for Western democracies, has been accepted as a standard at the international level ${ }^{14}$.

Strictly speaking, international standards in this area, primarily the rules of Special Annexes to the International Convention on the Simplification and Harmonisation of Customs Procedures, emphasize the need for the participating countries to fully ensure the declarants' ability to enjoy their rights to move goods in accordance with the desired way of further usage. For example, Standard 2, Section 2 of Special Annex B establishes that «Re-importation in the same state shall be allowed even if only a part of the exported goods is re-imported», or

${ }^{13}$ Bourgon J. Responsive, Responsible and Respected Government: Towards a New Public Administration Theory. International Review of Administrative Sciences. 2007. Vol. 73. No. 1. Pp. 7-26. URL: https://doi.org/10.1177/0020852307075686

${ }^{14}$ Kormych B. The Modern Trends of the Foreign Trade Policy Implementation: Implications For Customs Regulations. Lex Portus. 2018. № 5. Pp. 27-45 (39). URL: https://doi.org/10.26886/2524-101X.5.2018.2 
Standard 2, Section 1 of the Special Annex D specifies that «National legislation shall provide for Customs warehouses open to any person having the right to dispose of the goods (public Customs warehouses)»» ${ }^{15}$. At the same time, it is usually provided that respective procedures shall be directly established by national legislation. This type of standards basically creates a situation where, customs procedures itself may vary significantly in different countries, but in the same time the implications of application of such procedures shall be typical for any given country.

This conclusion brings us to ideas of transnational control over national administrative procedures and administrative decision making, that is pretty common for scholars sharing concepts of transnational or global administrative law. In brief this concerns covers the situation where «To ensure, even at a distance, that their and their constituencies" preferences are satisfied, the political actors of State A negotiating international commitments (ordinarily, but not necessarily, in the treaty form) can require State B's regulators to follow procedures of transparency, participation, reason-giving, and review» ${ }^{16}$.

Applying the transnational control approach, one may see, that despite any attempts to impose a local views upon the rules specifying ways and means of performing customs formalities, international standards are pushing national legislator and national administrative authorities towards the compliance to internationally recognized objectives of such formalities. Basically, in this particular case the force of international standards is focused on the shift from the state oriented to mutually advantaged or even private actor oriented rules.

And the very first rule that hits the clear administrative law approach to customs regimes is the rules of Art. $71 \mathrm{CCU}$ which, apparently, provide:

- the right of declarant «to choose the customs regime in which he wishes to place the goods, subject to the conditions of such a regime and in the manner prescribed by this Code»;

${ }^{15}$ International Convention On The Simplification And Harmonization Of Customs Procedures (As Amended). URL: http://www.wcoomd.org/en/topics/facilitation/ instrument-and-tools/conventions/pf_revised_kyoto_conv/kyoto_new.aspx

${ }^{16}$ Mertenskötter P., Stewart R. Remote Control: Treaty Requirements for Regulatory Procedures. IILJ Working Paper 2018/2. MegaReg Series. Institute for International Law and Justice. New York University School of Law. New York, 2018. P. 12. 
- the right of declarant to change «the customs regime in which the goods are placed... to another one, chosen by the declarant»;

- the specific way of placing goods under the chosen customs regime by means of «lodging a customs declaration and performing customs formalities».

All this does not comply with the general understanding of administrative legal regime as a set of rules to regulate a specific area, which is issued by the public authorities and which application is also initiated by public authorities. Contrary in the case of customs regimes, a non-state actor both choses, changes and initiates application of such regime to the goods in question.

When we talk about the choice of the customs regime by the declarant, this primarily concerns the choice between movement of goods into or out of the customs territory in the ordinary order (with the full taxation and application of non-tariff measures) or in the specific order (which provides the relief form customs duties and other taxes, not application of quantitive restrictions, etc). In the case of specific order, the proper preferences or reliefs are «exchanged» with the consent of the declarant to comply administrative restrictions on the usage of goods, submission of additional information, application of customs controls, etc. Consequently, the conditions of customs regimes are voluntary in that mean that the declarant always has the possibility to abandon them, by placing the good under different customs regime.

In this aspect, the entire system of customs regimes performs a coherence function. The respective legislation framework is to grant a coherence between securing interests of a State and meeting needs of non-state actors involved in foreign economic operations. Thus customs regimes comprise «a kind of general legal characterization of the main types of customs situations that determine the specific procedure for moving goods through the customs frontier, depending on its end-use (purpose of transition)»» ${ }^{17}$.

In a broader aspect, the system of customs regimes is an instrument for implementing modern trends to combine imperative and dispositive regulation within the administrative law to secure the maxima of rights

17 Шахмаметьев А.А. Таможенный режим по законодательству России и Франции: Сравнительное исследование на примере режима таможенного склада : автореф. дис ... канд. юр. наук: 12.00.14. М.: Академия управления МВД России, 2002. C. 18. 
and legitimate interests of non-state actors. After all, the initiation of legal relations concerning importation or exportation of goods and the picking up the purpose for which goods are destined, is complete depends upon a decisions of non-state actors. Thus, the non-state actors define a specific content of customs procedures that are applied to the goods. In this aspect, customs regimes become close to procedures for administrative services provision, since public-administrative actions are carried out on the initiative of a non-state actor (declarant), and the purpose of such actions is to create conditions for the realization of private rights and interests. The important peculiarity of dispositive legal regulation within customs regimes is that the freedom of declarant's choice is not absolute, since it is implemented within the framework of legislative requirements regulating the procedural activities of customs authorities. Hence, the limitations of choice are exhausted by the set of behavior patterns, that are represented by the list of customs regimes ${ }^{18}$.

In other words, each specific customs regime may be viewed as a system of procedural legislative rules, which regulates the application of substantive customs law in a given (typical) situation.

A customs regime serves as an envelope for exercising rights and obligations of state authorities and other persons involved in a particular situation a movement of goods through the customs border.

The appropriate «regime» rules are basically utilized to provide the functioning of customs authorities, indicating them how to conduct the customs clearance procedure. And the system of customs regimes, as a set of typical models for the movement of goods through the customs frontier, empowers the harmonization of the freedom of choice of declarants (that is a dispositive legal regulation) with the competence of customs authorities as governing subjects, which in accordance with Art. 19 of the Constitution of Ukraine «shall act only on the basis, within the limits of authority and in the manner envisaged by the Constitution and laws of Ukraine») ${ }^{19}$ (which is an imperative legal regulation).

For example, that is the exact point, the EU customs legislation is focused. For example Art. 150 of Union Customs Code (UCC) dealing with the choice of customs procedure provides, that «Except where

${ }^{18}$ Гречаний Д.М. Правові основи застосування митного режиму тимчасового ввезення : автореф. дис ... к.ю.н.: 12.00.07. Київ: МАУП, 2013. С. 8.

${ }^{19}$ Конституція України від 28.06.1996. Офіиійний вісник Украӥни. № 254к/96ВР 2010 р., № 72/1 Спеціальний випуск. Ст. 2598. 
otherwise provided, the declarant shall be free to choose the customs procedure under which to place the goods, under the conditions for that procedure, irrespective of their nature or quantity, or their country of origin, consignment or destination ${ }^{20}$.

At this point we face the need to make an important notice that the resolving individual cases in administrative law is considered not as regime, but as procedural issue. And precisely at these grounds one may draw the line between customs regimes and administrative legal regimes.

In addition, within the «procedural» concept, a customs declaration in the form of Single Administrative Document (SAD) receives its original meaning, that it is «not an exclusive customs document» but is «a substitute for many administrative forms» ${ }^{21}$. In this case, the SAD performs a dual function:

1) Upon a SAD submission it is an application initiating the administrative procedure, which is confirmed by its registration by the customs office;

2) Upon completion of customs clearance, a SAD becomes an administrative act, which contains decisions of the customs office to release goods, to recognize its customs value, classification, quantity, etc.

Hence we cannot go over the terminological dispute between «customs regime» or «customs procedure» ${ }^{22}$. Moreover, as a matter of fact, the term "customs regime» is used in a rather limited number of national legislations, instead international instruments and the EU customs law are adopting the therm «customs procedure». For example, due to WCO position «Customs Procedure means the treatment applied by the Customs to goods that are subject to Customs control» ${ }^{23}$.

It is possible, actually, to refer to the fact that the International Convention On The Simplification And Harmonization Of Customs Procedures uses the terms «procedure» and «regime» as synonyms in its English and French texts respectively. However, it should be understood

${ }^{20}$ Regulation (EU) № 952/2013 of the European Parliament and of the Council of 9 October 2013 laying down the Union Customs Code. OJ L 269. 10.10.2013. Pp. 1-101.

${ }^{21}$ The single administrative document (SAD). Characteristics. URL: http://ec.europa.eu/taxation_customs/sites/taxation/files/resources/documents/sad-characteristics_en.pdf

$\overline{22}$ Кормич Б.А. Митні режими як інститут митного права. Митна справа. 2013. № 6. C. $86-92$.

${ }_{23}$ Glossary Of International Customs Terms. D/2013/0448/20. Brussels: World Customs Organization, 2013. 
that the «regime approach» is the feature of French administrative law, which actually replaces the concept of procedures. For example, there is exist the concept of «institutions governed by administrative law regime» as the institutions which «perform the task of public service» ${ }^{24}$. So, in the operational aspect of the corresponding French term «regime» comprises the order in which public authorities perform the functions assigned to them. Finally, it should be noted that the term «regime» had been adopted by Ukrainian customs law something about 1994 not from the French customs legislation, but from the Russian Customs Code of 1993, and even in Russian Federation the term «regime» was later repelled.

The issue, in fact, should be viewed from a slightly different angle. That is the issue of the current focus of administrative law at the enforcing rights and legitimate interests of non-state actors in relations with state authorities, and the need to return the customs legislation in compliance with that principle, as well as, to adopt the modern principles of trade facilitation.

As it has been mentioned, Ukrainian national administrative law defines a procedure as a process of decision-making on an individual case, in the words that is a sequence of actions of a public authority in response to an application of a person exercising his or her rights. Contrary, a regime, in most cases, is a certain set of rules that in one way or another limits a usual procedure of exercising of human rights (state border regime, classified information regime, regime of emergency, etc.). In this respect the «regime» approach in customs legislation poorly conforms in line with the modern principles of free trade and trade facilitation, since it immediately entails ghosts of prohibitions and restrictions.

But from the point of «procedural» concept the issue looks quite different. For example, there is an import or export as a type of foreign trade transaction, in the sense of the Law of Ukraine «On Foreign Economic Activity» and there are procedures for import or export, as customs administration decision-making process for individual cases of movement of goods in question through the customs frontier. In other words we are dealing with a special type of administrative procedure. A person needs to import or export certain products, the law permits to do

${ }^{24}$ Брэбан Г. Французское административное право: Пер. с фр. / Под ред. и со вступ. ст. Боботова С. В.. М.: Прогресс, 1988. С. 52. 
so, and the person addresses the customs office to implement that right. The customs office, in turn, carry out a sequence of actions regarding issuing the permission. Thus, it is an ordinary service function of the state.

The flexibility of customs procedures and the right for initiation and changing procedures on the side of non-state subjects for a great extend corresponds with the basic idea of New Public Service - «serve, rather than steer $\gg^{25}$. Furthermore within this service function, the above discussed coherence between dispositive and imperative regulation provides achievement of the broader task to provide a framework to combine two different set of government's actions to meet its responsibilities «to facilitate individual self-interest» and «to promote citizenship, public discourse, and the public interest» ${ }^{26}$.

\section{Basic Elements of Customs Procedures}

To understand the basic design elements of a customs procedure it should be distinguished its three key elements, which are utilized in above mentioned WCO definition «treatment applied by the Customs to goods that are subject to Customs control» ${ }^{27}$ :

1) certain actions of a customs administration regarding the application of law - «a treatment that is applied by the customs»;

2) «goods» as a particular object of application of such treatment;

3) specific status of goods as a «subjects to customs control».

So, the customs procedure is a kind of decision-making process where a customs administration on request of a holder of procedure takes a decision to release or deny releasing the goods in question, which also may lead to a changing of a customs status of goods. The treatment itself may be described as a set of formalities that have to be performed in the course of such decision-making workflow. The respective «goods in question» comprise the object of the decision is to be made by customs authorities. Finally the term «being the subject to customs control» determines the time frames of the particular customs procedure, so far such procedures may be applied only within duration of customs control.

${ }^{25}$ Denhardt R., Denhardt J. The New Public Service: Serving Rather Than Steering. Public Administration Review. 2000. Vol. 60. No. 6. Pp. 549-559.

${ }^{26}$ Ibid. P. 557.

27 Glossary Of International Customs Terms. D/2013/0448/20. Brussels: World Customs Organization, 2013. 
Besides, considering the concept of customs procedure as a set of rules to resolve individual cases in typical customs situations makes possible to distinguish several peculiar characteristics of the customs procedure:

1) any given customs procedure is established to provide an application of customs legislation to goods entering or leaving a customs territory;

2) any given customs procedure corresponds to the typical situation in which particular goods are entering or leaving the customs territory;

3 ) the main functional purpose of customs procedure is to meet needs of citizens and enterprises for importation or exportation of goods;

4) the rules of customs procedure and supplementary substantive customs laws have a specific object of application, which is goods (products) in question;

5) customs procedures start with lodging of customs declaration;

6) customs procedures end when the declared purpose of placing the goods under such procedure is achieved.

The connection between the duration of customs procedure and application of customs controls to goods in question reviews an important differences between «general» customs procedures (like import or export) and specific customs procedures (for example, customs warehousing, inward or outward processing, etc.).

In the first case the purpose of placing goods under the customs procedure is achieved after the end of procedure and, respectively, release of goods form customs control. For example for import procedure such purpose shall be the free use of goods on the customs territory, which may be enjoyed right after the customs clearance.

As for specific customs procedures, the purpose for which goods are placed in such procedures, basically, is to be achieved during the term while the procedure is performed and respective goods are under customs supervision. For example it may be storage of goods placed under customs warehousing procedure or usage of goods placed under temporary admission procedure. The fact that goods are under customs supervision throughout the specific customs procedures emerges demands for holders of procedure to perform additional actions to finalize such procedures. Typically respective goods should be placed under another procedure that grants release for free circulation (import, 
re-import, re-export) or should be abandoned in accordance with legislation rules.

Thus the time frames of customs procedures are determined by legal actions (deeds) or emerging of legal facts.

The basic standard for customs legislation is that a customs procedure may be initiated only in specific manner of legal action, which is a customs declaration lodging. For example, The International Convention On The Simplification And Harmonization Of Customs Procedures (Section 1, Special Annex A) uses the definition «Customs formalities prior to the lodgement of the Goods declaration» which covers operations carried out from the time of introduction of goods into the customs territory «until goods are placed under a Customs procedure $\rangle^{28}$. National customs legislations are more specific on this subject. The already mentioned Art. 71(2) of CCU 2012 clearly states that «placing goods under customs regime is made by means of declaration» ${ }^{29}$. The same rule is provided in Art. 158 (1) UCC «All goods intended to be placed under a customs procedure... shall be covered by a customs declaration appropriate for the particular procedure $\gg$.

At the same time, a termination of a customs regime may be either due to a number of legal actions (release of goods, placing goods under another customs procedure, abandoning goods, confiscation of goods) or due to legal facts (damage or loss of goods due to force majeure). Besides, the maximum time limits for application of customs procedures may be set by legislation or, within such limits by the decision of customs authorities (as, for example, in the case of temporary admission).

Besides, the legislation may set territorial boundaries for application of certain customs procedures, which are narrower than the customs territory. Such territorial application may be limited to the territories of

${ }^{28}$ International Convention On The Simplification And Harmonization Of Customs Procedures (As Amended). URL: http://www.wcoomd.org/en/topics/facilitation/ instrument-and-tools/conventions/pf_revised_kyoto_conv/kyoto_new.aspx

${ }^{29}$ Митний кодекс України від 13.03.2012 № 4495-VI. Офіиійний вісник України. 2012. № 32. Ст. 1175.

${ }^{30}$ Regulation (EU) № 952/2013 of the European Parliament and of the Council of 9 October 2013 laying down the Union Customs Code. OJ L 269. 10.10.2013. Pp. 1-101. 
free zones (for respective customs procedures) or zones of customs control (for customs warehousing, duty-free trade, inward processing).

The regulations, which comprise in customs procedures, form a few blocs of rules focusing at different application aspects of said procedures. From our post of view, by analyzing the definition of Para 25, Art. $4 \mathrm{CCU}$ and rules of Title $5 \mathrm{CCU}$, it is possible to distinguish six blocs of such rules, which form the regulative space of any given customs procedure:

1) conditions for placing goods under the customs regime;

2) procedural rules for performing customs formalities;

3) rules for application of tariff measures;

4) rules for application of non-tariff measures;

5) a customs status of goods after release;

6) restrictions for use of goods after release.

Conditions for placing goods under a customs procedure can be divided in general conditions and specific conditions.

Under general conditions hereby is understood the regulations referring to Art. $196 \mathrm{CCU}$ prohibitions on the movement of certain goods across the customs frontier. Such prohibitions are applied to all goods arriving to the customs territory, thus the noncompliance makes it impossible to place such goods under any of customs procedure.

Special conditions are referred to regulations for placing goods under particular customs procedures. The later regulations basically provides four types of conditions:

- customs status of goods prior to placing under a customs procedure (Ukrainian goods or non-Ukrainian goods);

- direction of movement of goods (arriving or leaving the customs territory);

- restrictions on the movement of goods through the customs frontier (Art. 197 UCC), which shall be complied by the holder of procedure to complete the customs clearance;

- a need of obtaining a customs authorities' permission to place goods under certain procedures (for example, inward or outward processing).

As for procedural rules for performing customs formalities, the on of the interpretations of a customs procedure due to interpretation of Para 21, Art. $4 \mathrm{CCU}$ is «the complex of customs formalities and the order for its accomplishment».Customs formalities itself are defined as 
«a set of actions that are to be performed by citizens and enterprises on the one side and customs authorities on the other» (Para 29, Art. 4 CCU). The purpose of customs formalities is to provide compliance with the legislation, which in other words is the implementation of the substantive law.

Due to the Art. $186 \mathrm{CCU}$, the content of customs formalities in each case, apart from the chosen customs procedure itself, depends on:

- means of transport (which may be air, water, road, rail transport, pipelines and power supply lines);

- ways of transport (which determines by type of contract with carrier and include cargo shipments; accompanied baggage; unaccompanied baggage; hand luggage; international mail; international express shipments).

From the procedural point of view a customs procedure includes the sequence of proceedings, i.e.: lodging goods declaration; payment of customs duties; performing customs control measures; performing official and state control measures; completion of customs clearance, etc.

Rules for application of tariff measures are covered by the Art. 286 CCU «Imposition of duty on the goods moved across the customs border of Ukraine depending on the customs procedure». On that gourds Ukrainian customs legislation provides five types of taxation for goods arriving or leaving customs territory:

1) payment of all customs duties - the goods are subject to full taxation full in accordance with customs and tax legislation;

2) exemption from customs duties - goods are exempted from payment of customs duties, a repayment of previously paid duties and taxes may apply;

3) conditional full exemption from customs duties b - exemption from payment of the accrued customs debt is subject to compliance with the requirements of the customs procedure;

4) conditional partial exemption from customs duties under temporary admission procedure -3 presents of amount of duties and taxes payable for release for free circulation for each full or incomplete calendar month of the temporary importation;

5) conditional partial relief from import duty under outward processing procedure - positive difference between the amount of customs duty occurred for importation of the processed goods and duty 
was to be payed in case of importation of goods, exported for outward processing,

Rules for application of non-tariff measures, basically, included two standard cases, whether goods are the subject to non-tariff regulation of foreign trade (import and export procedures), or whether they are not.

National customs legislation provides two different customs statuses of goods - «Ukrainian goods» and «foreign goods». The customs statutes of «Ukrainian goods» (Para 61, Art, $4 \mathrm{CCU}$ ) covers goods: a) wholly obtained (produced) in the customs territory of Ukraine and not incorporating imported goods (b) goods imported to the customs territory of Ukraine and released for free circulation; (c) obtained (produced) on the customs territory of Ukraine from the goods of two above mentioned categories. Thus customs status of «foreign goods» refers to all goods, which are non «Ukrainian» ones. One of the key aspects of the application of chosen customs procedure is either maintaining the customs status of the goods, or changing it after the completion of the customs clearance. This fact is crucial for application of specific rules for usage of goods, placed under customs procedures.

Finally, restrictions for use of goods after release may be in forms of: 1) prohibition to sale or transfer to third parties; 2) prohibition to use goods; 4) prohibition to change the characteristics of goods. Depending on the chosen customs procedure, one or few of such restrictions may apply.

Considering two last points, in terms of the purpose of placing goods under a customs procedure it is possible to allocate two such basic purposed that are critical for holder of procedure: changing the customs status of the goods or obtaining permission to perform certain actions with goods without changing its customs status.

\section{The Classification of Customs Procedures: the Road to Europeanization}

Another issue that demands consideration is the classification of customs procedures in Ukrainian legislation, which according to Art. 70 CCU includes: import (release for free circulation); (2) re-import; export (final leave); re-export; transit; temporary import; temporary export; customs warehousing; free customs zone; duty-free trade; inward 
processing; outward processing; destruction or elimination; abandonment to the state $^{31}$. However, according to Annex XV to Chapter 5 of the Association Agreement between Ukraine and the EU on the approximation of customs legislation, the relevant articles of EU Modernized Community Customs Code 2008 (MCC) regulating customs procedures are listed as the rules requiring approximation of Ukrainian legislation to the acquis communautaire ${ }^{32}$.

Furthermore, the respective provisions of Association Agreement are based on repelled MCC $2008^{33}$, which is much different from current Union Customs Code 2013 in force ${ }^{34}$. This also appears to be the issue, so far comparing to the previous MCC 2008, the system of customs procedures, that is provided in current UCC 2013, is based on much more advanced logic with respect to the issues of exemption from taxes and performing the service functions of customs authorities.

The grounds of classification, as well as the structure of respective UCC Chapters, are drafted from the non-state actors' point of view. For example the division of procedures depends from whether goods are arriving or leaving the customs territory, and from existence of reliefs from customs duties under conditions of specific restrictions for goods' usage. Thus UCC provides not a simple list of procedures, but rather a guideline where the rules go after objectives of foreign trade operations.

In accordance with the classification of Art. 5 (16) UCC, there are only three types of customs procedures: release for free circulation, special procedures and export. Basically, such classification most accurately reflects the functional purpose of customs procedures application of tariff and non-tariff barriers. Accordingly, there are two procedures in which tariffs and non-tariff restrictions are fully applied «import» and «export», as well as «special procedures» that provide exemptions from customs duties and other trade policy measures under certain conditions.

${ }^{31}$ Митний кодекс України від 13.03.2012 № 4495-VI. Офіиійиний вісник України. 2012. № 32. Ст. 1175.

${ }^{32}$ Association Agreement between the European Union and its Member States, of the one part, and Ukraine, of the other part. OJ L 161. 29.5.2014. Pp. 3-2137.

${ }^{33}$ Regulation (EC) No.450/2008 of the European Parliament and of the Council of 23 April 2008 laying down the Community Customs Code (Modernised Customs Code). OJ L 145. 04.06.2008.

${ }^{34}$ Regulation (EU) № 952/2013 of the European Parliament and of the Council of 9 October 2013 laying down the Union Customs Code. OJ L 269. 10.10.2013. Pp. 1-101. 
Besides, this system of customs procedures has a number of operational features.

In particular, the UCC does not distinguish the re-import as a separate customs procedure, regarding it to be an integral part of the release for free circulation procedure (Art. 201 UCC), which serves as the basis for relief from import customs duties (Article 203 UCC «Returned Goods»).

As for the goods taking out of the EU customs territory, the UCC refers to both export (Art. 269 UCC) and re-export (Art. 270 UCC). But due to the general approach adopted in the Title VIII of UCC export and re-export rather are the varieties of a single procedure for Union-goods and non-Union goods, respectively. Such thesis gets its confirmation in the aforementioned classification of customs procedures in accordance with Art. 5 (16) UCC, which defines a single export procedure. Besides, within the Chapter VIII of the UCC in almost the same manner treats a temporary export, which is not a separate customs procedure, but as the grounds for goods in question to «benefit from export duty relief, conditional upon their re-import» (Art. 277 UCC «Exemption from export duty for Union goods temporarily exported»).

The Art. 210 UCC provides four categories of special procedures, which include:

(a) transit, which shall comprise external and internal transit;

(b) storage, which shall comprise customs warehousing and free zones;

(c) specific use, which shall comprise temporary admission and end-use;

(d) processing, which shall comprise inward and outward processing.

Within this list, the end-use procedure worth to be highlighted, so far despite a total number of fourteen customs procedures, Ukrainian legislation does not provide any analogy. According to Art. 254 (1) UCC «under the end-use procedure, goods may be released for free circulation under a duty exemption or at a reduced rate of duty on account of their specific use». Thus, the UCC treats all cases of application of tax preferences due to specified end-use as a separate customs procedure. Contrary Ukrainian legislation views such cases as a tax benefits (Art. $282 \mathrm{CCU}$ ) or as a special duty treatment of certain products 
(Art. $287 \mathrm{CCU}$ ), which are applied within frameworks of an ordinary import procedure.

The EU approach to this issue looks quite logical, so far the goods subject to application of tax benefits cannot be viewed as released for free circulation for a full extent, since, on the one hand, the holder of procedure has to comply with the conditions for providing said tax benefits, on the other hand the customs authorities have to supervise that compliance.

Therefore, within the framework of the end-use procedure, UCC explicitly provides the powers of customs administrations to establish conditions for prior authorization «under which the goods shall be deemed to have been used for the purposes laid down for applying the duty exemption or reduced rate of duty» (Art. 254 (2) UCC, and to verify compliance with such conditions «in order to avoid abuse, customs supervision shall continue for a period not exceeding two years after the date of their first use for the purposes laid down for applying the duty exemption or reduced rate of duty» (Art 354 (3) UCC).

On the other hand, we can define a series of customs procedures existing in Ukrainian legislation, which are not considered as a separate customs procedures due to the acquis communautaire. For example Title $\mathrm{V}$ UCC «GENERAL RULES ON CUSTOMS STATUS, PLACING GOODS UNDER A CUSTOMS PROCEDURE, VERIFICATION, RELEASE AND DISPOSAL OF GOODS», includes Chapter 4 «Disposal of Goods», which are a kind of actions, which the owner of goods, or customs authorities may perform before placing good under customs procedure. The actions for the disposal of goods include: destruction of goods (Art. 197 UCC), the sale of goods (Art. 198 (1) UCC), abandoning goods to the State (Art. 199 UCC). But, once again, all these measures are merely a legal facts, which are the reason for the termination or initiation of customs procedures.

That position is clarified in the provisions of Art. 198 (2) UCC, which sets up the both cases, providing that:

- Non-Union goods which have been abandoned to the State, seized or confiscated shall be deemed to be placed under the customs warehousing procedure. They shall be entered in the records of the customs warehousing operator, or, where they are held by the customs authorities, by the latter. 
- Where goods to be destroyed, abandoned to the State, seized or confiscated are already subject to a customs declaration, the records shall include a reference to the customs declaration. Customs authorities shall invalidate that customs declaration.

Furthermore, according to the Art. 198 (1) UCC, measures for the disposal of goods may be taken on the initiative of the customs authority in an exhaustive list of cases.

Finally, the UCC does not specify a customs procedure, which can be similar to the Ukrainian duty-free trade procedure. At the same time, duty-free shops are considered as a specific way of application of the customs warehousing procedure in which the retail sale of goods placed in such procedure is permitted. This approach is commonly used in the current practice of customs regulation. For example, in the same manner it is applied in the US law, which classifies duty-free stores as «class 9 warehouses» ( $§ 19.35$ US Code $)^{35}$.

\section{CONCLUSIONS}

Current Ukrainian system of customs procedures is based on a mix of old post-soviet tradition of administrative law and modern international legal standards for customs procedures emerged within WCO frameworks. The traditional «administrative» part tries to view respective rules as a specific types of administrative legal regimes, which is more state-focused approach intended to impose extra limits on international trade in goods. Thus it is hardly compatible with internationally backed trends of trade facilitation.

Contrary, the international standards in the field promote a procedural approach, where customs procedures are treated as a rules of proceeding for application of substantive customs laws. The latter approach is rather focused on meeting needs and enforcing rights and legal interests of non-state actors of international trade. Thus the shifting from «regime» views to «procedure» ones may contribute implementation of trade facilitation measures due to obligations ether within WCO Kyoto Convention and WTO Trade Facilitation Agreement.

Thus customs procedures should be understood as a sets of certain rules of proceeding binding customs authorities and other persons

${ }^{35}$ US Code. $\S 19.35$. 
concerned towards performing customs formalities, and in some cases, other border formalities. In this respect customs procedures are a specific typed of administrative procedures utilized for performing border administration. So far the customs legislation provides a set of customs procedures representing typical purposes of shipping goods onto or out the customs territory, which is accompanied by rights of the declarant to choose and change a customs procedure, the whole system is granted sufficient flexibility to meet needs and demands of the modern international trade. In this respect customs procedures sets the order of resolving individual cases for obtaining permission to bring goods into or out the customs territory.

Besides, customs procedures are traditionally connected with entire State financial system and also with foreign trade policy in general, so far the application of the chosen custom procedure triggers up the application of the tax legislation and the legislation on quantitative restrictions on foreign trade. Hereby, the other function of customs procedures is to set a system of reliefs from customs duties and nontariff measures, which is proposed in exchange for compliance with certain restrictions on usage of goods on customs territory.

The fact that customs procedures are bind with international standards makes them to influence the whole system of public administration in the field bringing it in compliance with general principles of good governance fostering in a number international instruments dealing with the trade facilitation. Thus in a broad view the development of modern customs procedures is a part of emerging trends of transition from current New Public Management to New Public Service concept in State administration.

Finally, the realization of tasks related to the approximation of Ukraine's customs legislation to the customs acquis communautaire requires the introduction of amendments to the $\mathrm{CCU}$ in order to establish a harmonized term «customs procedure» and to bring the system of such customs procedures in line with the UUC 2013. Of course, the last task entails the necessity of reforming of supplementary secondary legislation. But, due to the declared European integration tasks of Ukraine, it makes sense to ensure the development of customs legislation in maximum harmonization with international and European standards. 


\section{SUMMARY}

The present paper provides the analyses of the concept of customs procedures, which is adapted in Ukrainian legislation with respect to such issues as conformity with the modern trends in public administration, international standards on trade facilitation and approximation to EU customs rules. The hypothesis is based on conclusions that the history of the modern approach to customs procedures can be traced back to the beginning of 19-th century when the customs has widely adopted a different treatment to goods due to declared purposed for its introduction into the customs territory. Thus the diversity of customs procedures provided different cases for reliefs form customs duties and, respectively, different workflows for a customs clearance of such goods. It is also argued, that different approaches to the terminology, which is used in customs legislation, namely the utilization of terms «customs regime» or «customs procedure» may reflect different understanding of the role and functions of customs authorities towards the border management. In Ukrainian case, the use of term «customs regimes» is caused by post-soviet heritage in the issues of public administration, that is badly comparable with the modern trends of trade facilitation. Thus the adoption of the concept of «customs procedures», which are a specific type of administration procedures, looks very promising, concerning the implementation of obligations of international instruments, such as WTO Trade facilitation agreement. Besides, the «customs procedures» concept is more relevant the current focus of public administration on meeting needs of private actors, whilst protecting public interests. To that end the important role place the internal design of customs procedures, which is also discussed in the paper. Finally, the obligations within Association Agreement between Ukraine and EU towards the approximation of customs legislation appears to be the decisive factor the development of Ukrainian system of customs procedures for the nearest decades. With this respect the paper reviews the main differences between the EU customs procedures and the Ukrainian ones to reveal the possible ways and means of the approximation.

\section{REFERENCES}

1. Брэбан Г. Французское административное право: Пер. с фр. / Под ред. и со вступ. ст. Боботова С. В. М.:Прогресс, 1988. 488 с. 
2. Гречаний Д.М. Правові основи застосування митного режиму тимчасового ввезення : автореф. дис ... к.ю.н.: 12.00.07. Київ: МАУП, 2013. 21 с.

3. Кивалов С.В. Средства осуществления таможенной политики Украины .Одесса: Астропринт, 1995. 256 с.

4. Конституція України від 28.06.1996. Офіційний вісник України. № 254к/96-ВР 2010 р., / № 72/1. Спеціальний випуск. Ст. 2598.

5. Кормич Б.А. Державно-правовий механізм митної політики України : монографія. Одеса: Астропринт, 2000. 180 с.

6. Кормич Б.А. Історія розвитку митної справи в Європі: періодизація та основні тенденції. Lex Portus. 2016. № 1. С. 51-63.

7. Кормич Б.А. Митні режими як інститут митного права. Митна справа. 2013 . № 6. С. 86-92.

8. Крестьянинов О.О. Правове регулювання митних режимів : автореф. дис... канд. юр. наук: 12.00.07. Х.: Національна юридична академія України ім. Ярослава Мудрого, 2008. 19 с.

9. Митний кодекс України від 13.03.2012 № 4495-VI. Офіиійний вісник України. 2012. № 32. Ст. 1175.

10. Настюк В.Я. Белєвцева В.В. Адміністративно-правові режими в Україні : монографія. Харків: Право, 2009. 128 с.

11. Шахмаметьев А.А. Таможенный режим по законодательству России и Франции: Сравнительное исследование на примере режима таможенного склада : автореферат дис ... канд. юр. наук: 12.00.14. М.: Академия управления МВД России, 2002. 18 с.

12. Asakura H. World History of the Customs and Tariffs. World Customs Organization, 2003. 306 p.

13. Association Agreement between the European Union and its Member States, of the one part, and Ukraine, of the other part. OJ L 161. 29.5.2014. Pp. 3-2137.

14. Bourgon J. Responsive, Responsible and Respected Government: Towards a New Public Administration Theory. International Review of Administrative Sciences. 2007. Vol. 73. № 1. Pp. 7-26. URL: https://doi.org/10.1177/0020852307075686

15. Convention and Statute on Freedom of Transit. Barcelona, 20 April of 1921. League of Nations Treaty Series. Vol. 7. Pp. 12-33. 
16. Denhardt R., Denhardt J. The New Public Service: Serving Rather Than Steering. Public Administration Review. 2000. Vol. 60. № 6. Pp. 549-559.

17. Encyclopedia Britannica Dict. A.S.L.G.I. 11th Ed. Chisholm. 1910-1911-1922. 33 vols. Vol. 4. P. 200. URL: https://archive.org/ stream/EncyclopaediaBritannicaDict.a.s.l.g.i.11thed.chisholm.19101911-1922.33vols/04.EncycBrit.11th.1910.v.4.BIS-CAL.\#page/n217/ mode/2up

18. Glossary Of International Customs Terms. D/2013/0448/20. Brussels: World Customs Organization, 2013.

19. International convention on the simplification and harmonization of customs procedures (As Amended). URL: http://www.wcoomd.org/en/topics/facilitation/instrument-andtools/conventions/pf_revised_kyoto_conv/kyoto_new.aspx

20. International Convention Relating to the Simplification of Customs Formalities, and Protocol of Signature. Geneva, 3 November 1923. Australian Treaty Series. 1925. № 14.

21. Kormych B. The Modern Trends of the Foreign Trade Policy Implementation: Implications For Customs Regulations. Lex Portus. 2018. № 5. P. 27-45. https://doi.org/10.26886/2524-101X.5.2018.2

22. Mertenskötter P., Stewart R. Remote Control: Treaty Requirements for Regulatory Procedures. IILJ Working Paper 2018/2. Mega Reg Series. Institute for International Law and Justice. New York University School of Law. New York, 2018. 51 p.

23. Nicali A. Customs History. A Historical Outlook on the Italian Customs Policy. Ed. by G. Favale. URL: https://www.agenziadoganemonopoli.gov.it/portale/documents/20182/23 94935/storiadogane_uk.pdf/26ebc323-eac9-4cd7-8fa7-621b7d2daeb8

24. Regulation (EC) No.450/2008 of the European Parliament and of the Council of 23 April 2008 laying down the Community Customs Code (Modernised Customs Code). OJ L 145. 04.06.2008.

25. Regulation (EU) № 952/2013 of the European Parliament and of the Council of 9 October 2013 laying down the Union Customs Code. OJ L 269. 10.10.2013. Pp. 1-101.

26. Robinson M. From Old Public Administration to the New Public Service. Implications for Public Sector Reform in Developing Countries. Singapore: UNDP Global Centre for Public Service Excellence. 2015. 
20 p. URL: https://www.undp.org/content/dam/undp/library/capacitydevelopment/English/Singapore\%20Centre/PS-Reform_Paper.pdf

27. The single administrative document (SAD). Characteristics. URL: http://ec.europa.eu/taxation_customs/sites/taxation/files/resources/ documents/sad-characteristics_en.pdf

28. US Code. $\S$ 19.35. URL: https://www.ecfr.gov/cgi-bin/textidx?SID=3434bae86dee6528a7d3bfa443b5649b\&mc=true \&tpl=/ecfrbro wse/Title19/19cfr19_main_02.tpl

Information about the author: Kormych B. A. Doctor of Law, Professor, Head of the Department of Maritime and Customs Law, National University «Odesa Law Academy» 23, Fontanska Road, Odesa, 65009, Ukraine 